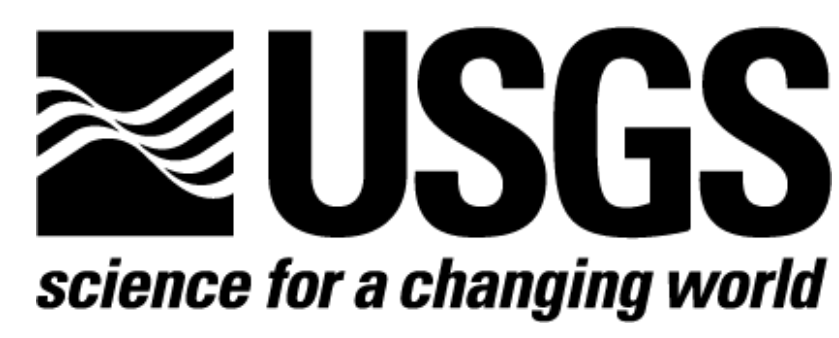

Prepared in cooperation with the Bureau of Land Management

\title{
Anderson Ranch Wetlands Hydrologic Characterization in Taos County, New Mexico
}

By Amy E. Galanter, Zachary M. Shephard, and Pamela Herrera-Olivas

Open-File Report 2019-1100

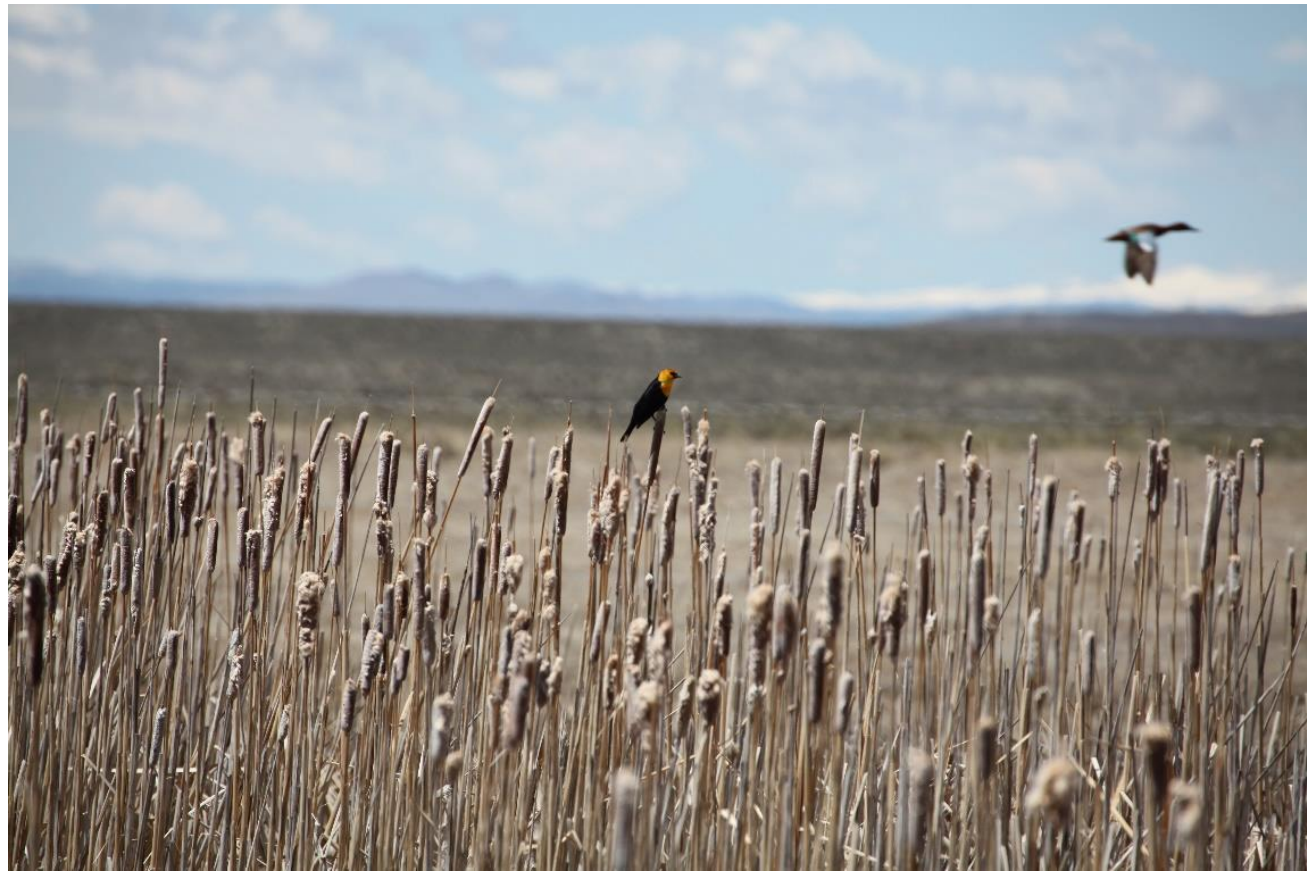

Yellow-headed blackbird and blue-winged teal at the Anderson Ranch wetlands, May 2016. Photograph by Fred Gebhardt, U.S. Geological Survey. 


\section{U.S. Department of the Interior \\ DAVID BERNHARDT, Secretary}

U.S. Geological Survey

James F. Reilly II, Director

U.S. Geological Survey, Reston, Virginia: 2019

For more information on the USGS-the Federal source for science about the Earth, its natural and living resources, natural hazards, and the environment-visit https://www.usgs.gov/ or call 1-888-ASK-USGS (1-888-275-8747).

For an overview of USGS information products, including maps, imagery, and publications, visit https://store.usgs.gov/.

Any use of trade, firm, or product names is for descriptive purposes only and does not imply endorsement by the U.S. Government.

Although this information product, for the most part, is in the public domain, it also may contain copyrighted materials as noted in the text. Permission to reproduce copyrighted items must be secured from the copyright owner.

Suggested citation:

Galanter, A.E., Shephard, Z.M., and Herrera-Olivas, P., 2019, Anderson Ranch wetlands hydrologic characterization in Taos County, New Mexico: U.S. Geological Survey OpenFile Report 2019-1100, 42 p., https://doi.org/10.3133/ofr20191100.

\section{ÆUSGS}




\section{Acknowledgments}

The authors would like to acknowledge the Natural Resource Damage Assessment and Restoration Program of the U.S. Department of the Interior for funding this research as well as the Bureau of Land Management and the U.S Fish and Wildlife Service for their collaboration on this project. The authors also acknowledge the vegetation survey team: USGS employees Quan Dong, Joan Daniels, and Alanna Jornigan. The authors also thank the landowners who have allowed data collection on their property. 


\section{Contents}

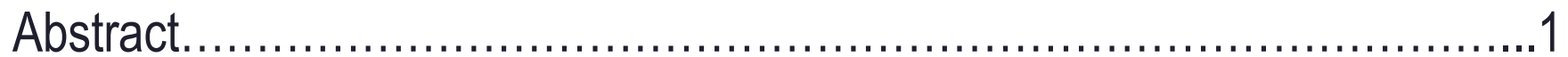

Purpose and Scope................................................................... 2

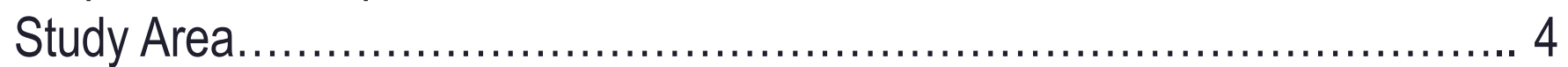

Study Approach ...................................................................... 8

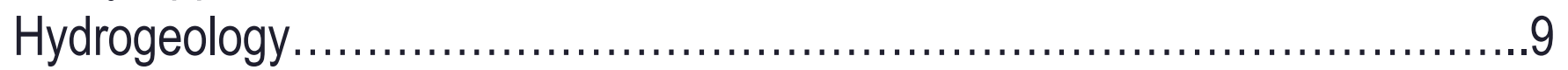

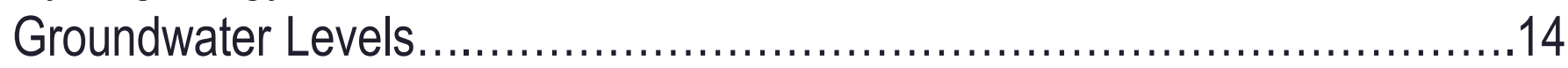

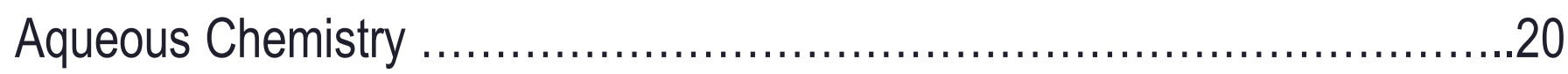

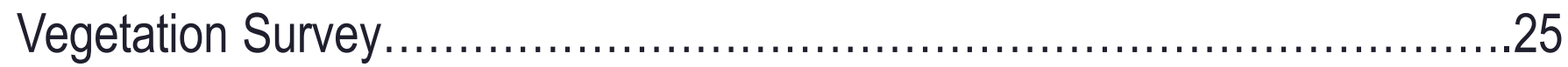

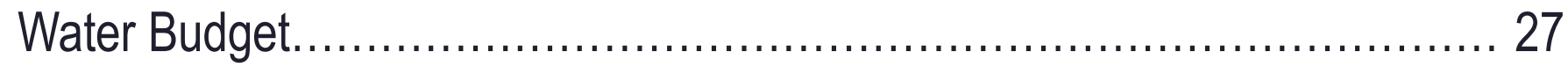

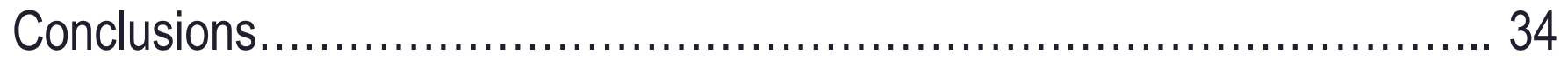

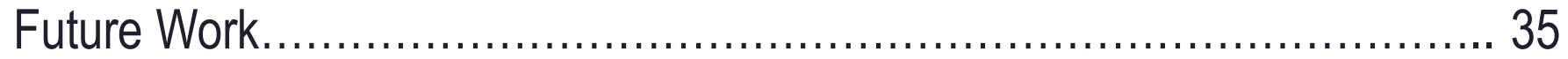

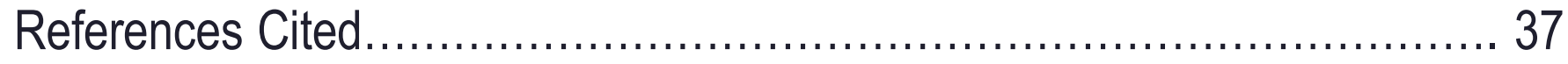

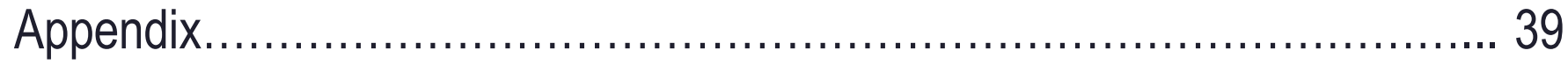




\section{Abstract}

The Anderson Ranch property (study area), located in Taos County, north-central New Mexico, was transferred from Chevron Mining, Inc. (CMI) to the Bureau of Land Management (BLM) as part of a Natural Resource Damage Assessment and Restoration (NRDAR) court-ordered settlement. The study area supports freshwater emergent wetlands and freshwater ponds. The settlement states that CMI will provide the land and a monetary settlement to support the restoration of the wetlands on the property. To best manage the study area, the BLM requires an understanding of potential effects of climate variability and groundwater withdrawals on the wetland function. This study, completed by the U.S. Geological Survey in cooperation with the BLM, provides an initial hydrologic characterization of the study area, which included literature review, collection of groundwater-level and aqueous-chemistry data, completion of a vegetation survey, and preliminary data analysis. The data compiled, collected, and analyzed as part of this study indicate that the wetlands within the study area are groundwater fed and that the water maintaining the wetlands is modern. Surface-water levels in the pond and groundwater levels in the surrounding wetland fluctuate seasonally. The hydraulic gradient in the study area is from northeast to southwest. Evapotranspiration is a main driver of water demand within the study area.

\section{ఇUSGS}


- The purpose of this study is to provide a hydrologic characterization of the Anderson Ranch wetlands that can be used to guide management strategies.

- This objective was met through literature review, data collection (groundwater-level data, aqueous-chemistry data, and a vegetation survey), and preliminary data analysis.

- The purpose of this Open-File Report is to communicate the results of the first phase of the study. This interim product can be used by BLM to determine the next steps of the study. 


\section{Eong-Term Questions for BLM}

- 50- to 100-year scenarios for the wetlands.

- Determining the value of investment in this property.

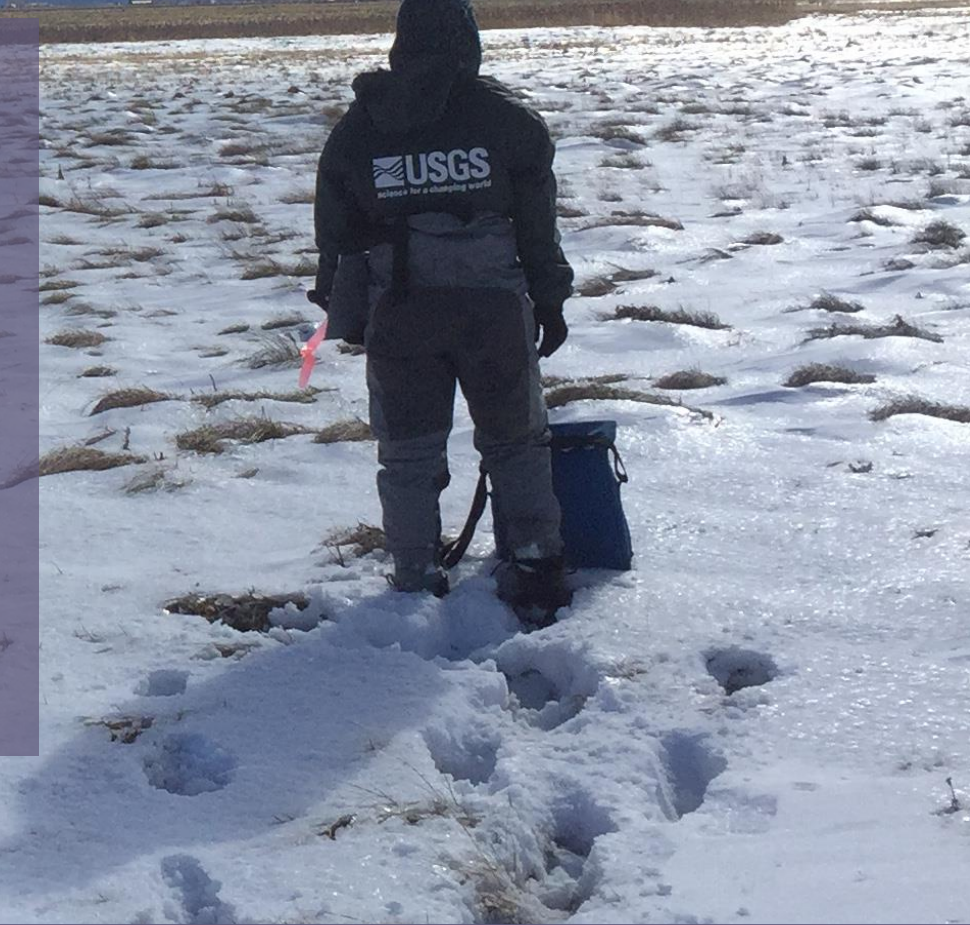

Anderson Ranch Wetlands Hydrologic Characterization, Purpose and Scope, slide 3 


\section{Study Area}

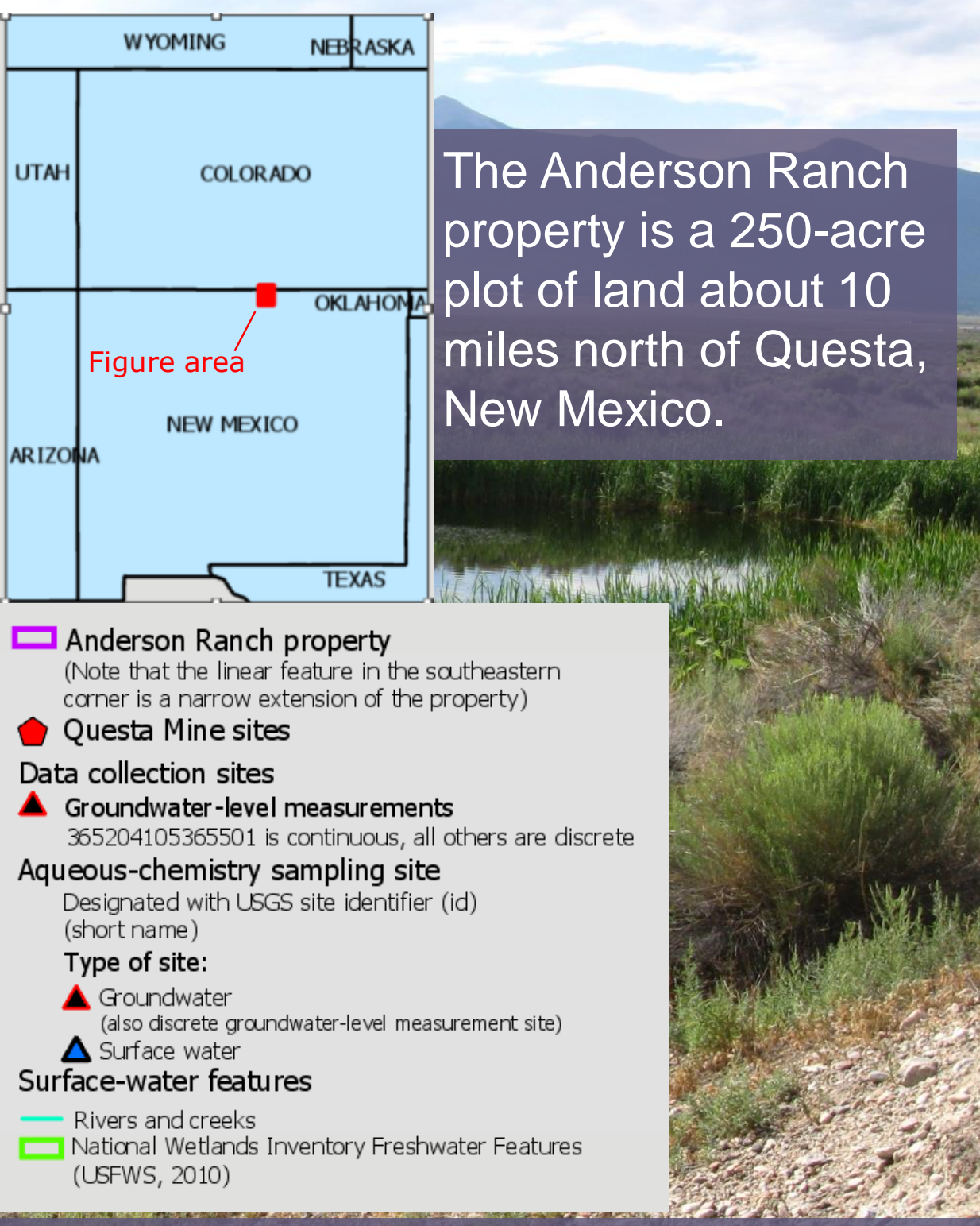

Anderson Ranch Wetlands Hydrologic Characterization, Study Area, slide 4 


\section{Anderson Ranch Property Background}

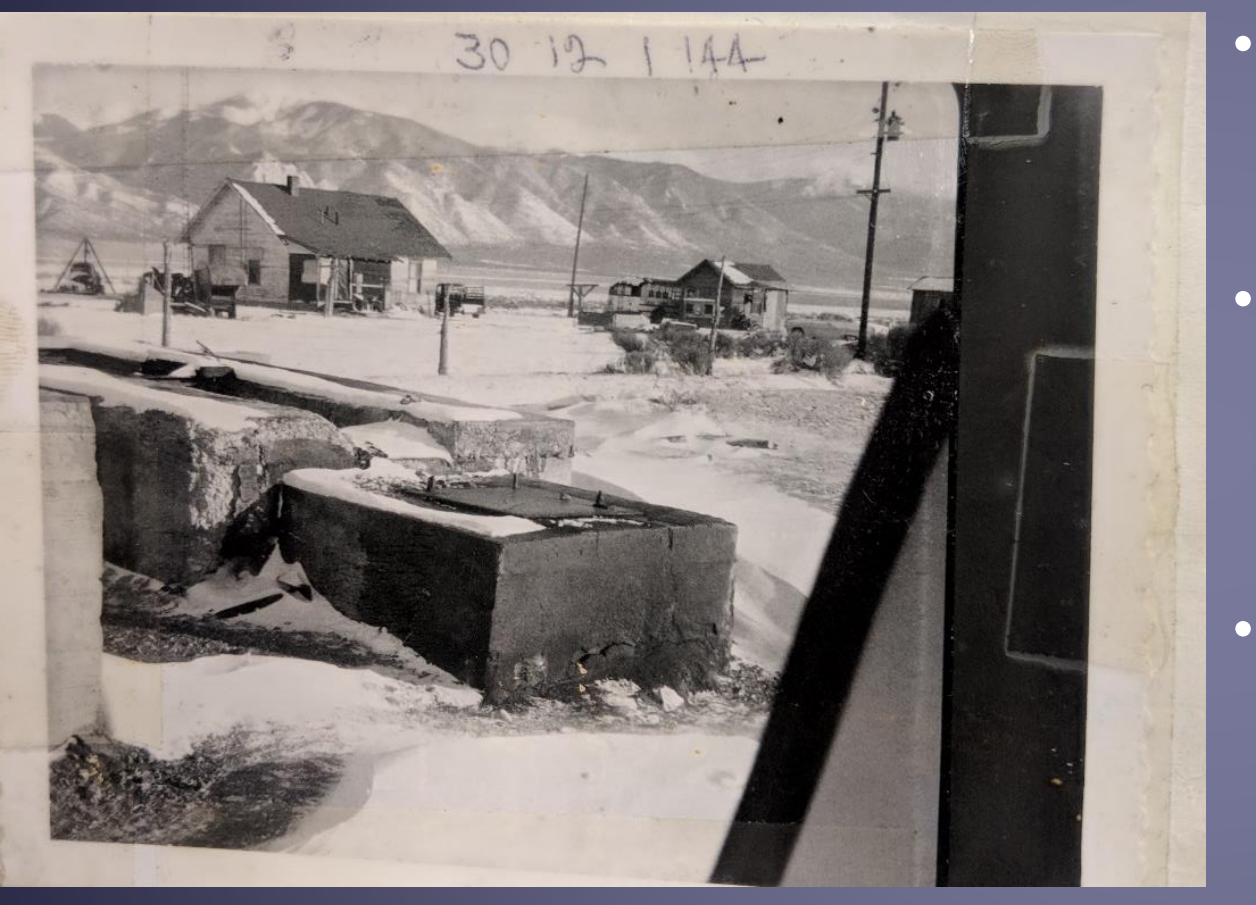

Anderson Ranch property, from USGS archives for site number 365159105364801 (circa 1970s).
- 1955-1964: Property was used for irrigation (NMOSE, 2019).

- 1964: Owner and operator of the Questa mine filed for a water right transfer (NMOSE, 2019).

- 2002-2017: Natural Resource Damage Assessment was conducted (DOI and others, 2018).

- 2018: Property was officially transferred to BLM (DOI and others, 2018).

\section{\#USGS}




\section{Past Indicators of Wetlands}

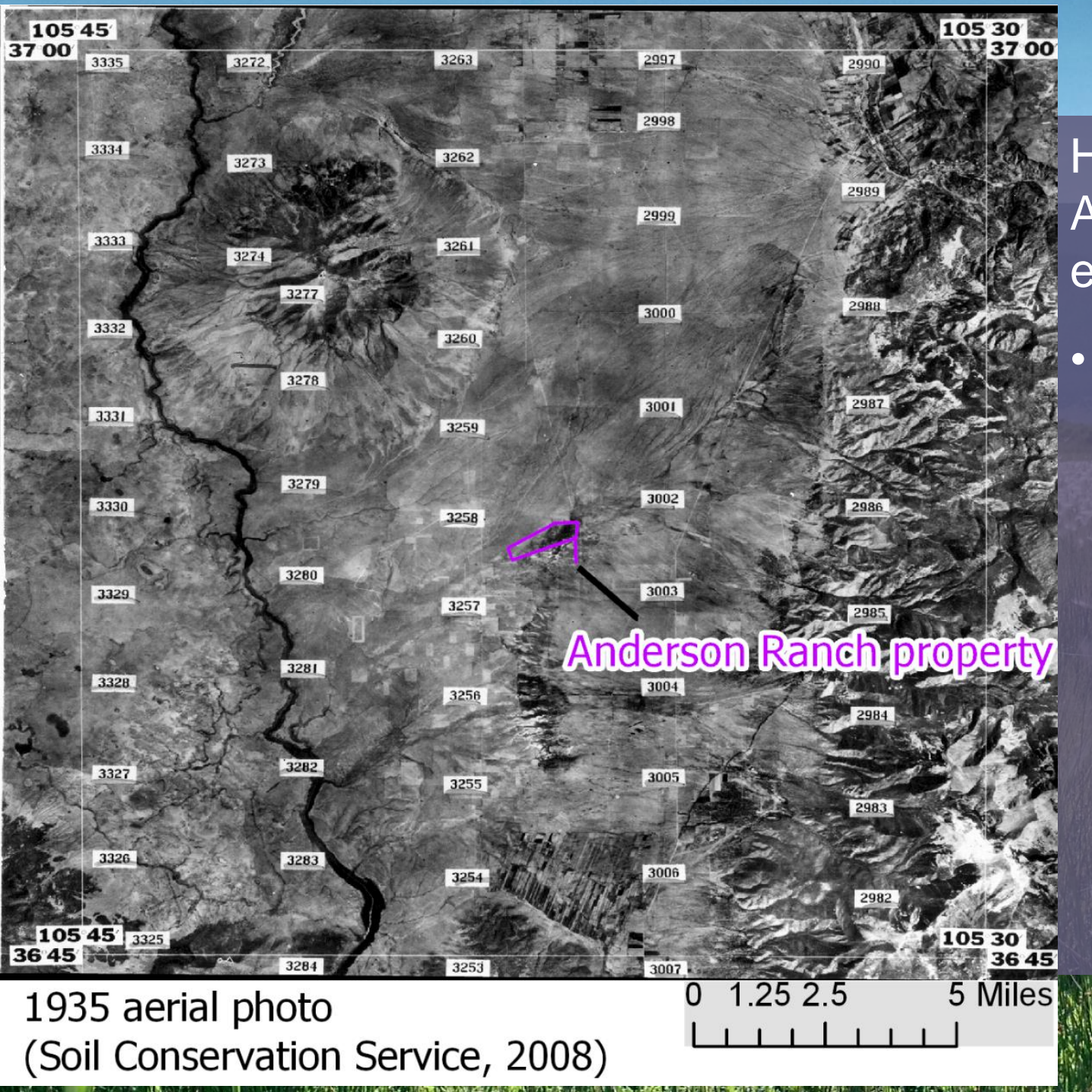

Historical imagery indicates that the Anderson Ranch wetlands have existed at least since 1935.

Within the Anderson Ranch property, there is no volcanic outcropping at the land surface. The dark color from the 1935 image within the property boundary aligns with the National Wetlands Inventory (USFWS, 2010). Therefore, the darker color within and near the current wetlands extent is assumed to indicate the presence of wetlands in 1935 .

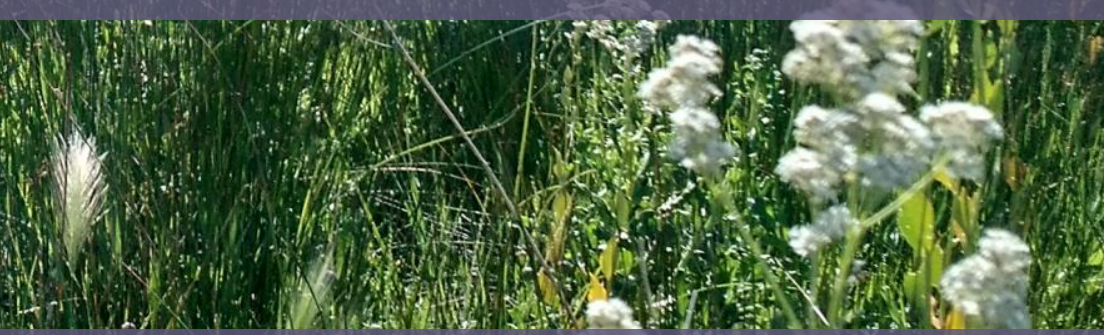




\section{Wetlands in New Mexico}

- Wetland landscapes are rare in New Mexico, and wetland habitat has shrunk in the last 200 years (Fretwell and others, 1996).

- Wetlands provide unique habitat for diverse ecosystems and many organisms, notably migratory waterfowl and wading birds (Fretwell and others, 1996; EPA, 2017).

- Wetlands serve important functions for watersheds, with potential for waterquality improvement and carbon storage (EPA, 2017).

- Connectivity between wetlands can affect resilience of wetlands and populations that depend on the wetlands for habitat (Uden and others, 2014).

- National Wetlands Inventory (USFWS, 2010) shows connectivity of freshwater-wetland features in the study area.

\section{$\approx U S G S$}




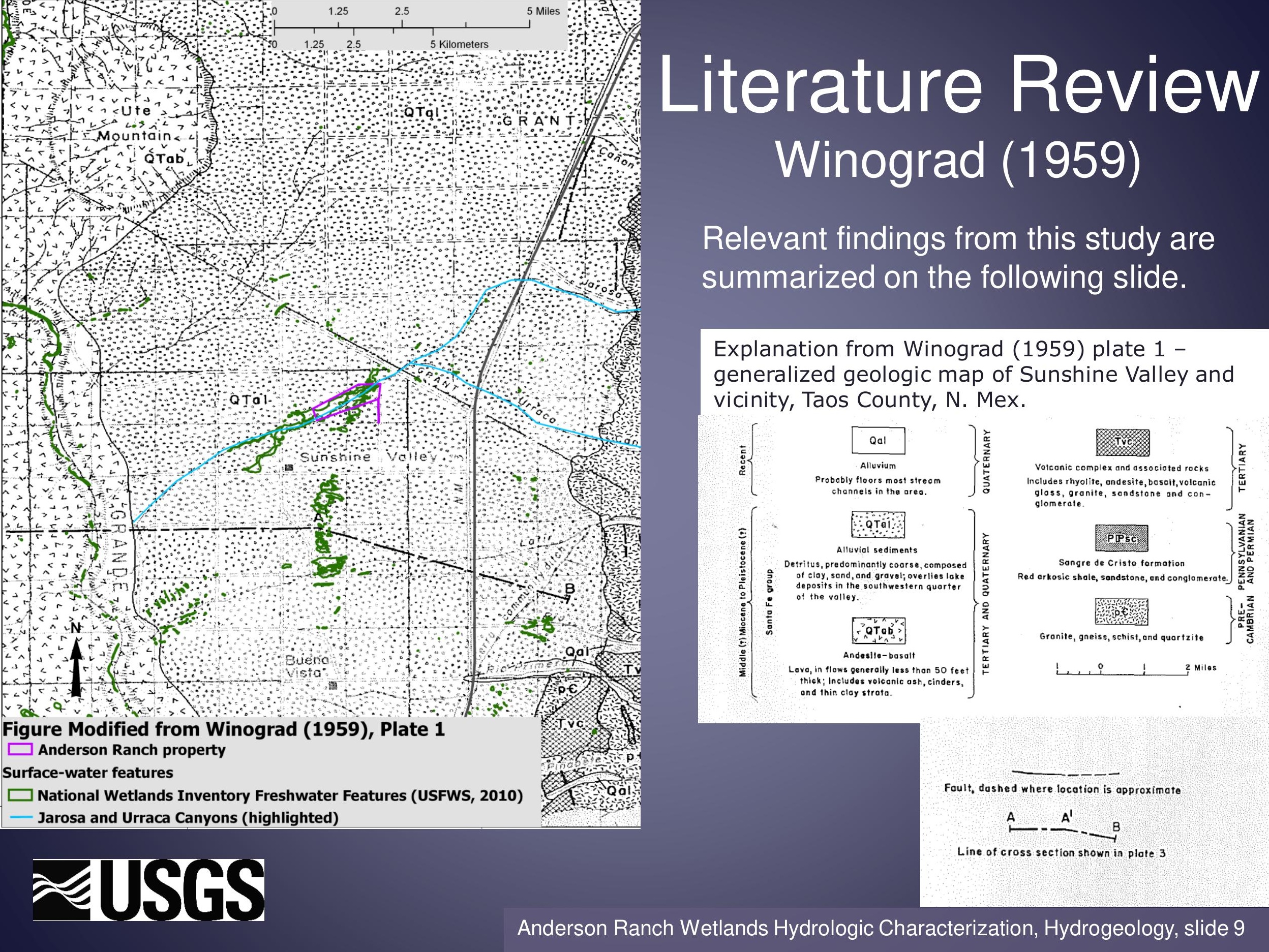




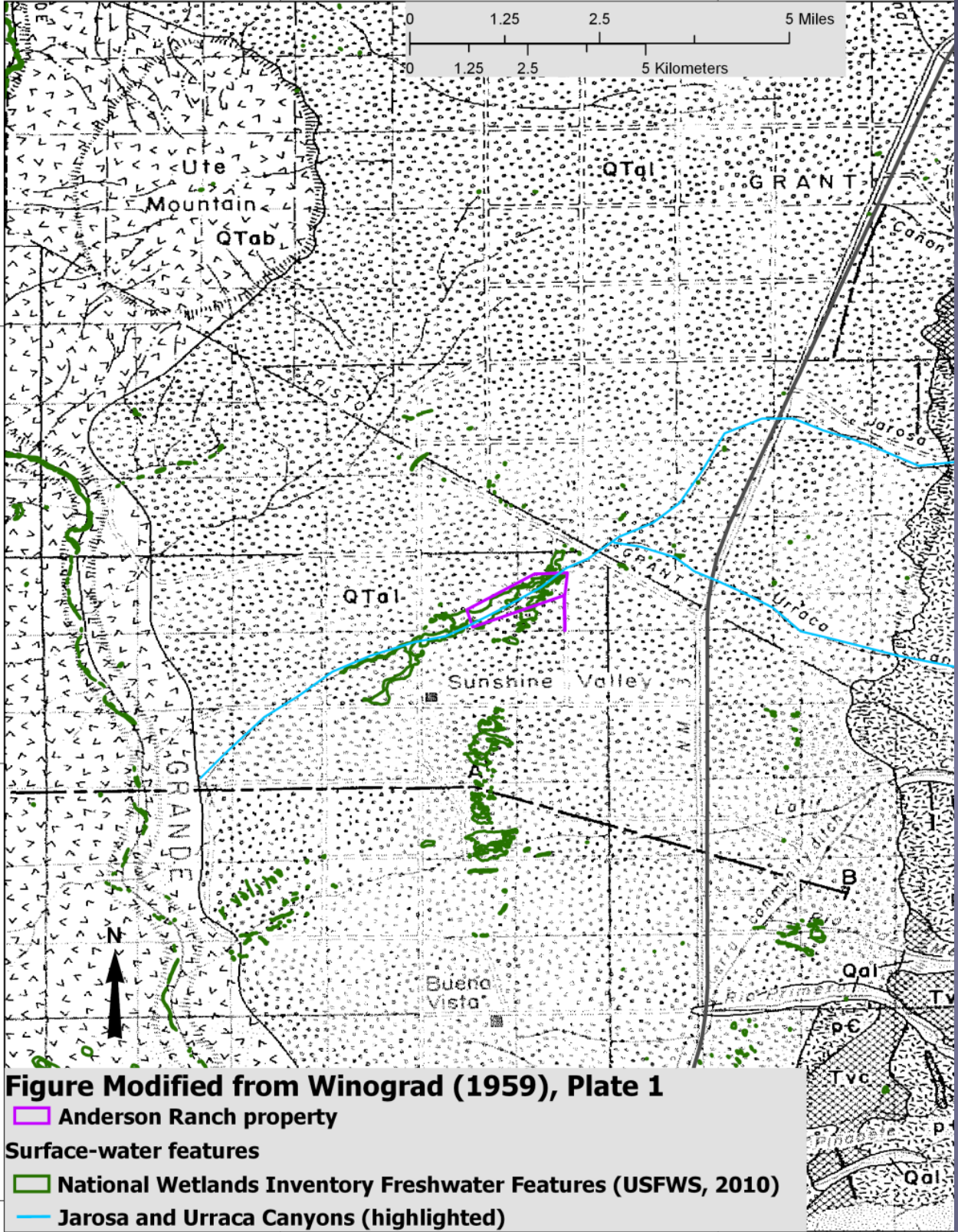

ÆUSGS
Literature Review Winograd (1959)

Findings shown in this figure as well as within Winograd (1959):

- Sunshine Valley, the valley between the Sangre de Cristo Mountains on the east and the Rio Grande on the west, is a piedmont alluvial plain and contains alluvial sediments interbedded with lava as well as lacustrine sediments.

- Groundwater underlying the Sunshine Valley discharges to the Rio Grande.

- Groundwater is recharged from perennial streams, arroyo flood flows, direct infiltration, canals and irrigation infrastructure.

- Jarosa and Urraca Canyons (highlighted in blue) converge north of the Anderson Ranch wetlands. 


\section{New Mexico} $\because$
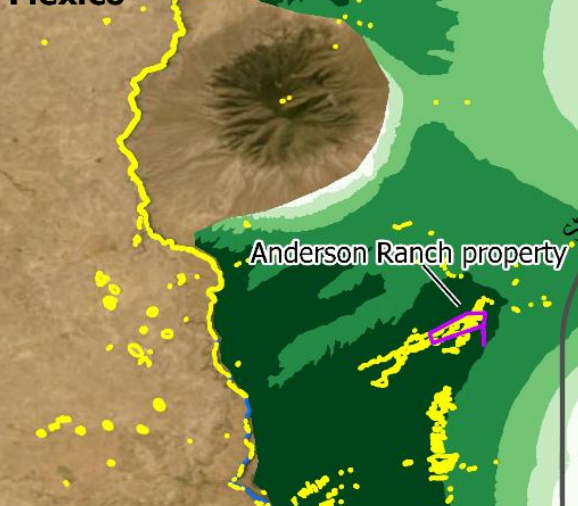

\section{$\therefore$}
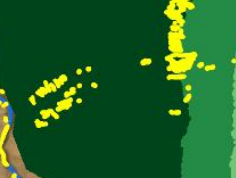

\section{Elevation} Analysis

\section{Classifying lower elevations} with smaller bins and natural jenks ${ }^{1}$ illustrates that the Anderson Ranch property and the wetlands to the south are in a topographic low.

${ }^{1}$ Natural jenks is an option in ArcGIS that clusters data based on data distribution.
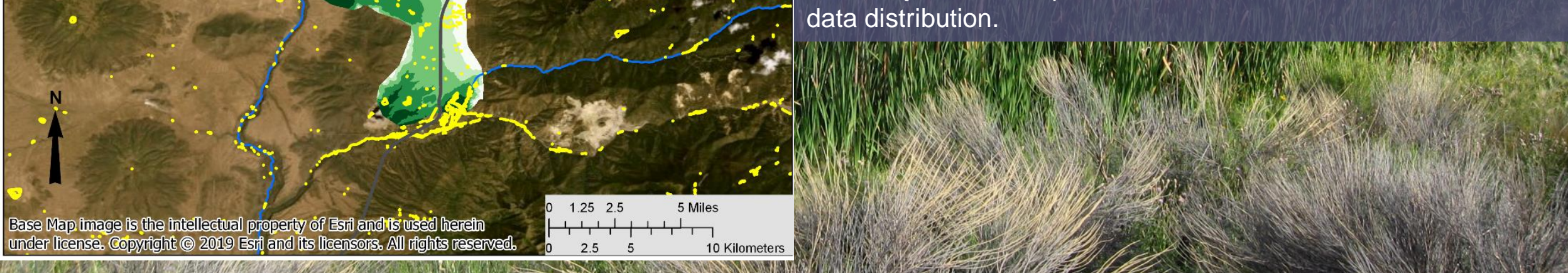


\section{Groundwater-Level and Temperature Data}

\section{(Groundwater-Level Data Available at USGS [2019])}

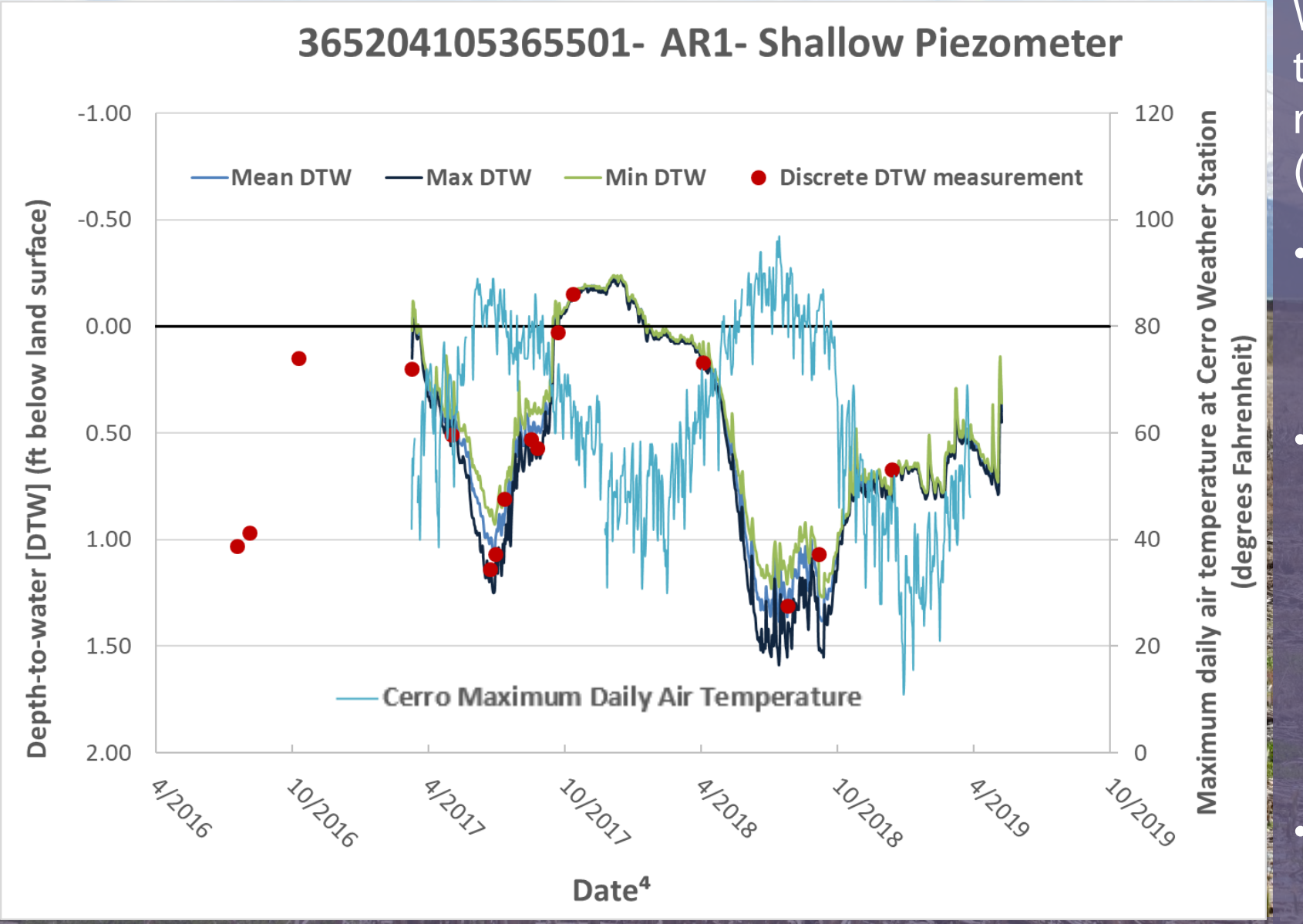

4 Tick marks on the horizontal axis are for every 180 days to delineate a rough estimate of evapotranspiration and non-evapotranspiration seasons.
When compared with air temperature data from the nearby Cerro Weather Station

- Groundwater levels declined during warmer months and rose during cooler months.

- Daily groundwater levels fluctuated more during warmer months, as indicated by the difference between the maximum ( $\max$ ) and minimum (min) depth-towater (DTW).

- Continued data collection and further time-series analysis could yield a better understanding of the seasonality of groundwater levels. (NOAA, 2019): 


\section{Groundwater-Level Data at Cerro}

Monitoring Well (Groundwater-1evel data avalable at UsGS [2019)]

\section{EUSGS}

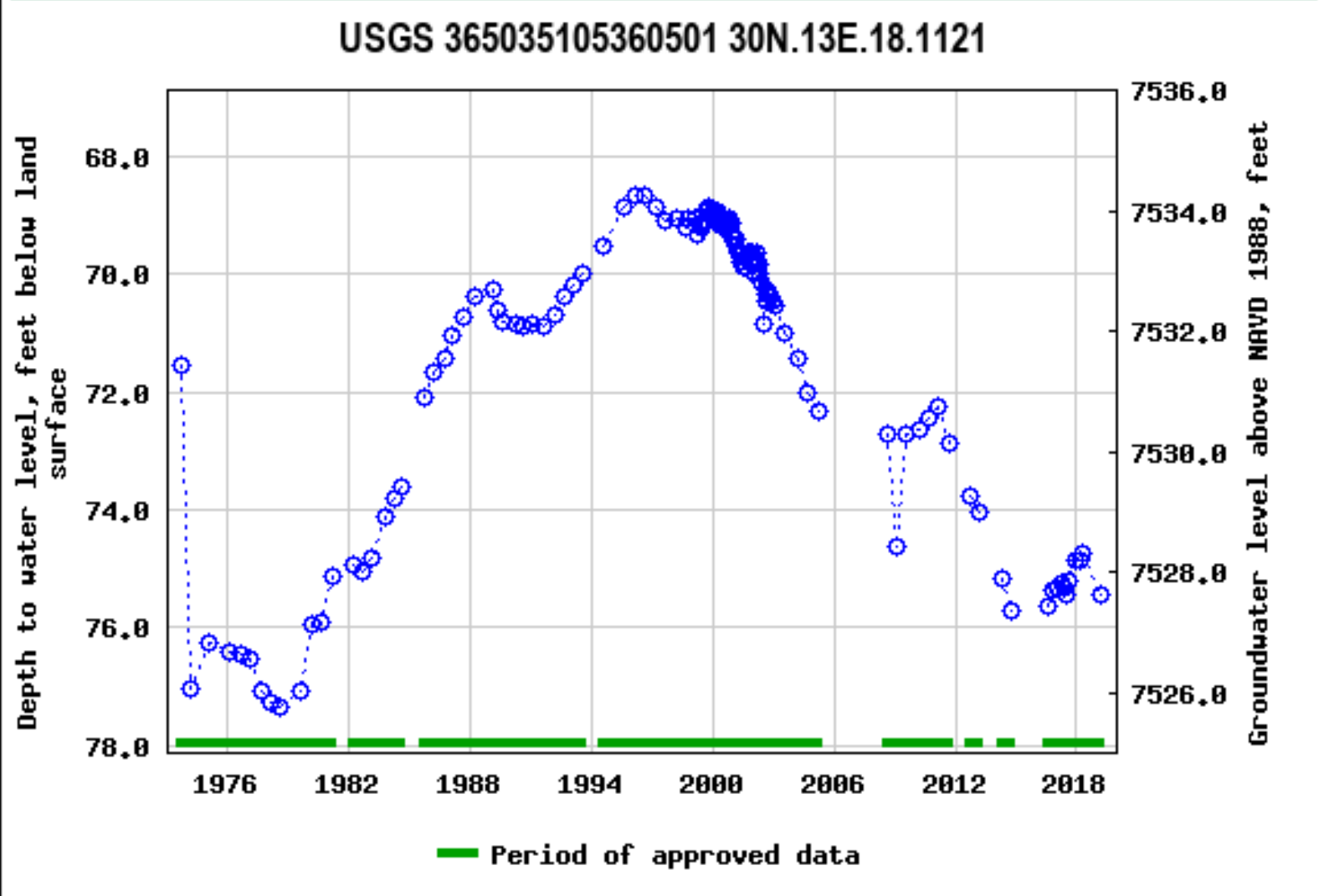

- 46-year period of record at the Cerro monitoring well shows an upward trend in groundwater-levels during the $1980-2000$ period and a downward trend in groundwater levels during 2000-2015 period.

- Precipitation and climate data analysis along with groundwater-level data analysis could yield information about correlations between precipitation, climate, and groundwater levels. 
Groundwater-Level

\section{Elevations and}

Contours

- Hydraulic gradient within wetland area is about 20 feet per mile.

- Groundwater flows from northeast to southwest.

- Hydraulic gradient and groundwater flow direction did not change much with season.

- The old agricultural well outside of wetlands area has a similar groundwater-level elevation, despite a deeper well depth and greater distance from wetlands. 


\section{Aqueous-Chemistry}

\section{Sampling}

(Aqueous-chemistry data available at USGS [2019] and in Appendix)

- Sites (locations shown on slides 4 and 8) Surface water - North Pond

Piezometer - AR1

Stock Well

- Constituents

Field properties (temperature, specific conductance, dissolved oxygen, $\mathrm{pH}$, turbidity, alkalinity), nutrients, major ions, trace elements, isotopes

\section{- Quality-control samples}

Surface-water and groundwater blank, groundwater replicate

\section{$\approx$ USGS}




\section{Aqueous Chemistry: Major lons}

(Aqueous-chemistry data available at USGS [2019] and in Appendix)

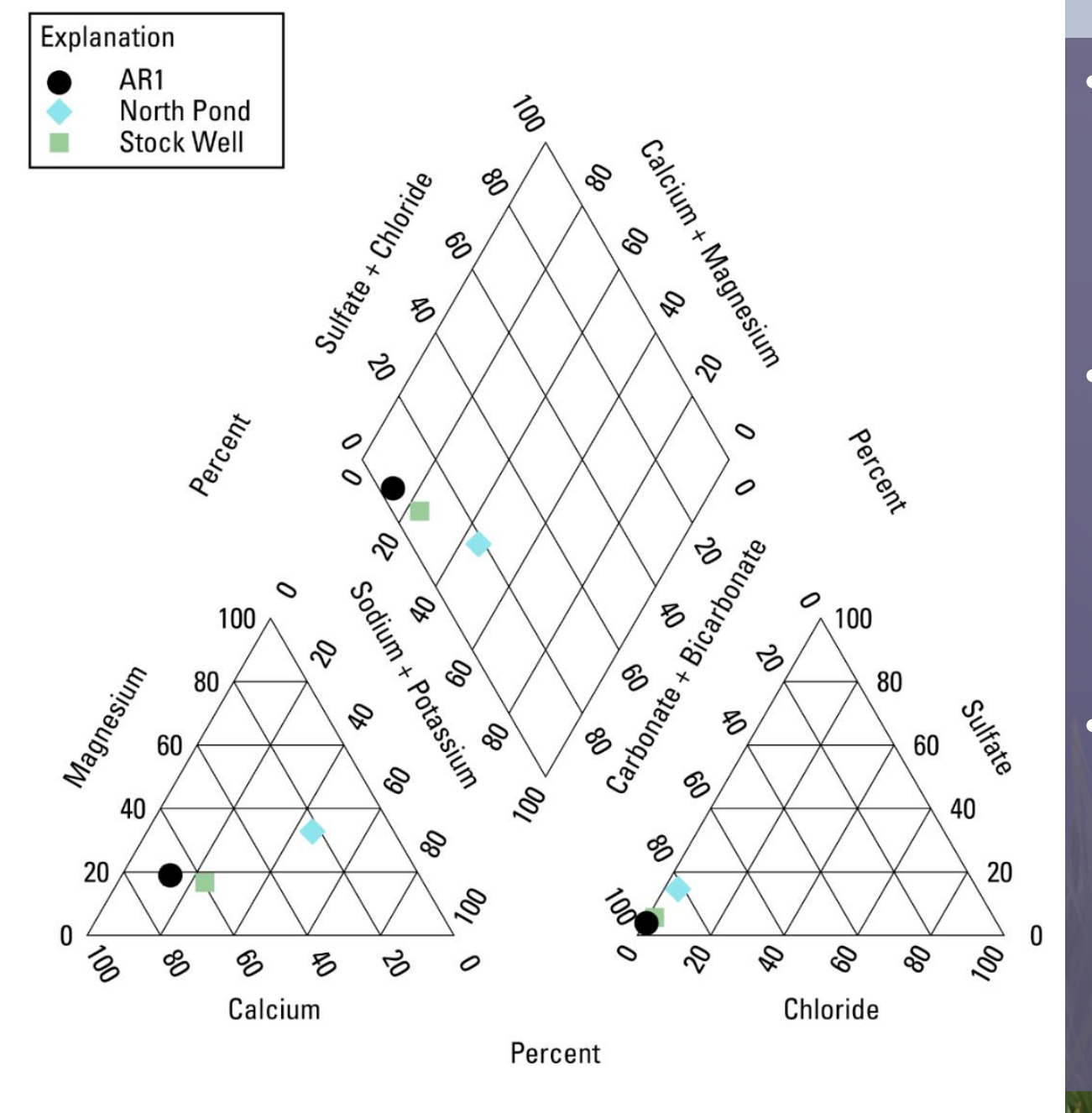

- A piper diagram is a trilinear diagram useful for illustrating the hydrochemical facies of a water sample (Hem, 1985).

- Based on major ion composition, both groundwater samples are calcium-bicarbonate water type and the surface-water sample is a mixed-cation bicarbonate type.

- Possible explanations for water-type difference at the surface-water site:

- An evaporative signal at the surface-water site.

- Cation exchange occurring within clay layers (Hem, 1985). 


\section{Aqueous Chemistry: Stable Isotopes}

(Aqueous-chemistry data available at USGS [2019] and in Appendix)

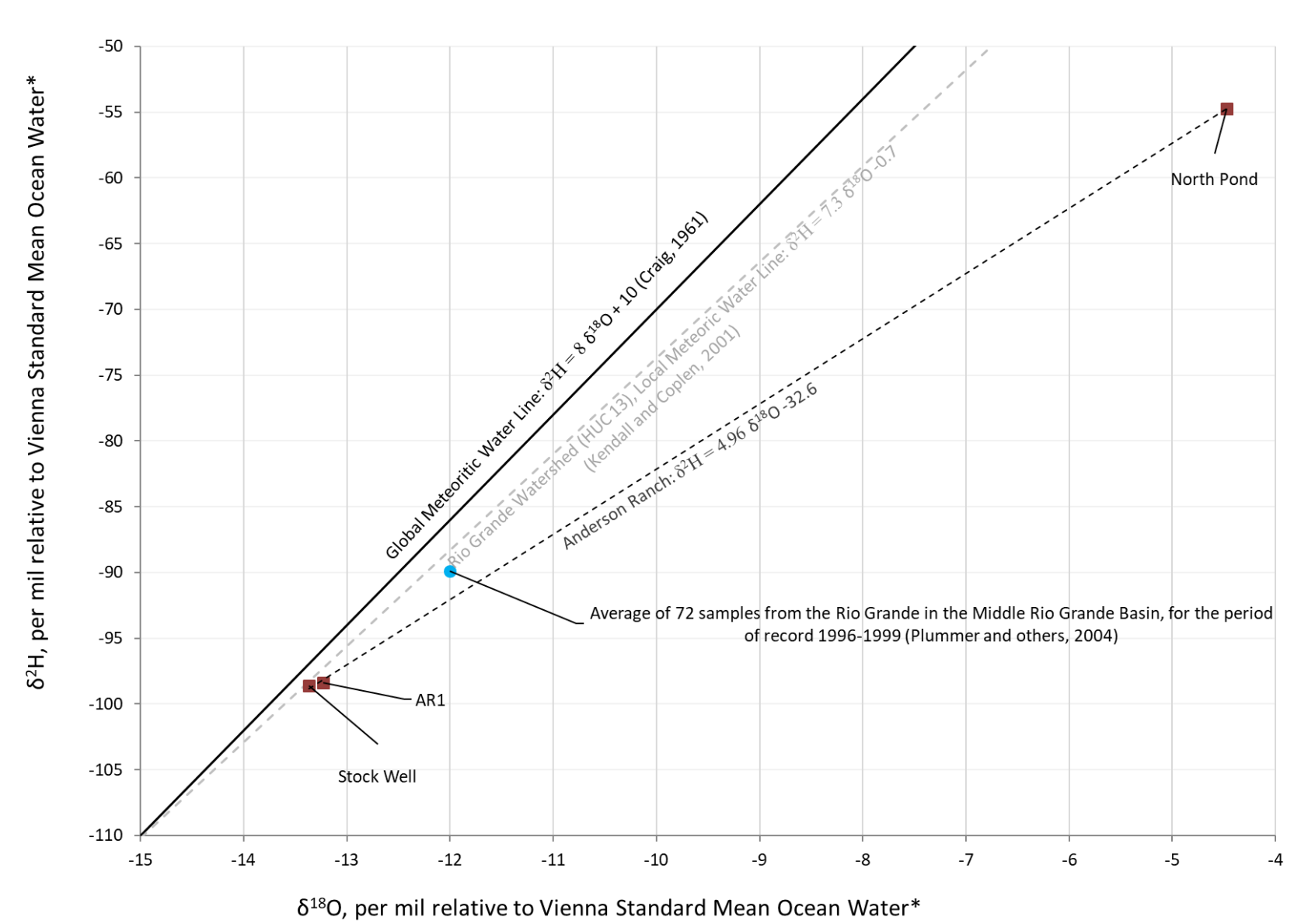

\section{$\approx$ USGS}

- The black dashed line connecting the Anderson Ranch sites is an estimated evaporative trend.

- The composition of the North Pond surface-water sample compared with the groundwater sample indicates evaporative fractionation.

*Please see the Appendix for an explanation of $\delta$. 


\section{Aqueous Chemistry: Nitrate, Dissolved Solids, and Isotopes}

(Aqueous-chemistry data available at USGS [2019] and in Appendix)

\begin{tabular}{|c|c|c|c|}
\hline Parameter & North Pond & AR1 & Stock Well \\
\hline Nitrate as Nitrogen & $<0.040$ & 3.39 & 1.34 \\
\hline $\begin{array}{l}\delta * 15 \mathrm{~N} / 14 \mathrm{~N} \\
\text { (per mil) }\end{array}$ & NA & 5.61 & 5.13 \\
\hline $\begin{array}{l}\delta^{*}{ }^{18} \mathrm{O} /{ }^{16} \mathrm{O} \text {, Nitrate } \\
\text { water filtered (per } \\
\text { mil) VSMOW }\end{array}$ & NA & -2.25 & -2.31 \\
\hline $\begin{array}{l}\text { Dissolved solids } \\
\text { dried at } 180^{\circ} \\
\text { Celsius (mg/L) }\end{array}$ & 549 & 277 & 164 \\
\hline $\begin{array}{l}{ }^{14} \mathrm{C} \text { percent } \\
\text { modern carbon, } \\
\text { normalized }\end{array}$ & NA & 112.6 & 98.92 \\
\hline Tritium (pCi/L) & NA & 19.3 & 12.7 \\
\hline
\end{tabular}

Age-dating tracers ${ }^{14} \mathrm{C}$ and tritium indicate recent recharge to shallow and deeper groundwater systems.

*Please see the Appendix for an explanation of $\delta$.

Vienna Standard Mean Ocean Water

${ }^{7} 2018$ EPA drinking water standard, Maximum Contaminant Level (EPA, 2018).
- Nitrate levels at AR1 are higher than the surface-water sample and Stock Well nitrate levels, but still below the Federal drinking water standard of $10 \mathrm{mg} / \mathrm{L}^{7}$

- Even low levels (greater than 2 $\mathrm{mg} / \mathrm{L}$ ) of nitrate as nitrogen have been found to affect aquatic organisms (Edwards and others, 2006; Edwards and Guillette, 2007).

- With further analysis, isotopes of nitrate could be used to identify the source of nitrogen at the wetlands.

\section{$\approx$ USGS}




\section{Aqueous Chemistry Summary (Aqueous-chemistry data available at USGS [2019] and in Appendix)}

- Groundwater and surface-water samples showed similar ionic compositions and low dissolved solids.

- Slightly higher dissolved solids and greater sodium and potassium concentrations in the surface-water sample indicates additional processes affecting the surface water.

- Radiocarbon and tritium activities measured in groundwater samples indicate that most of the groundwater is composed of recent recharge.

- Groundwater samples plotted on the Local Meteoric Water Line (Rio Grande Watershed [HUC 13]), and the stable isotope composition of the surface-water sample indicates evaporative fractionation.

- Nitrate levels were slightly elevated (greater than 2 mg/L) at AR1. 


\section{Vegetation Survey}

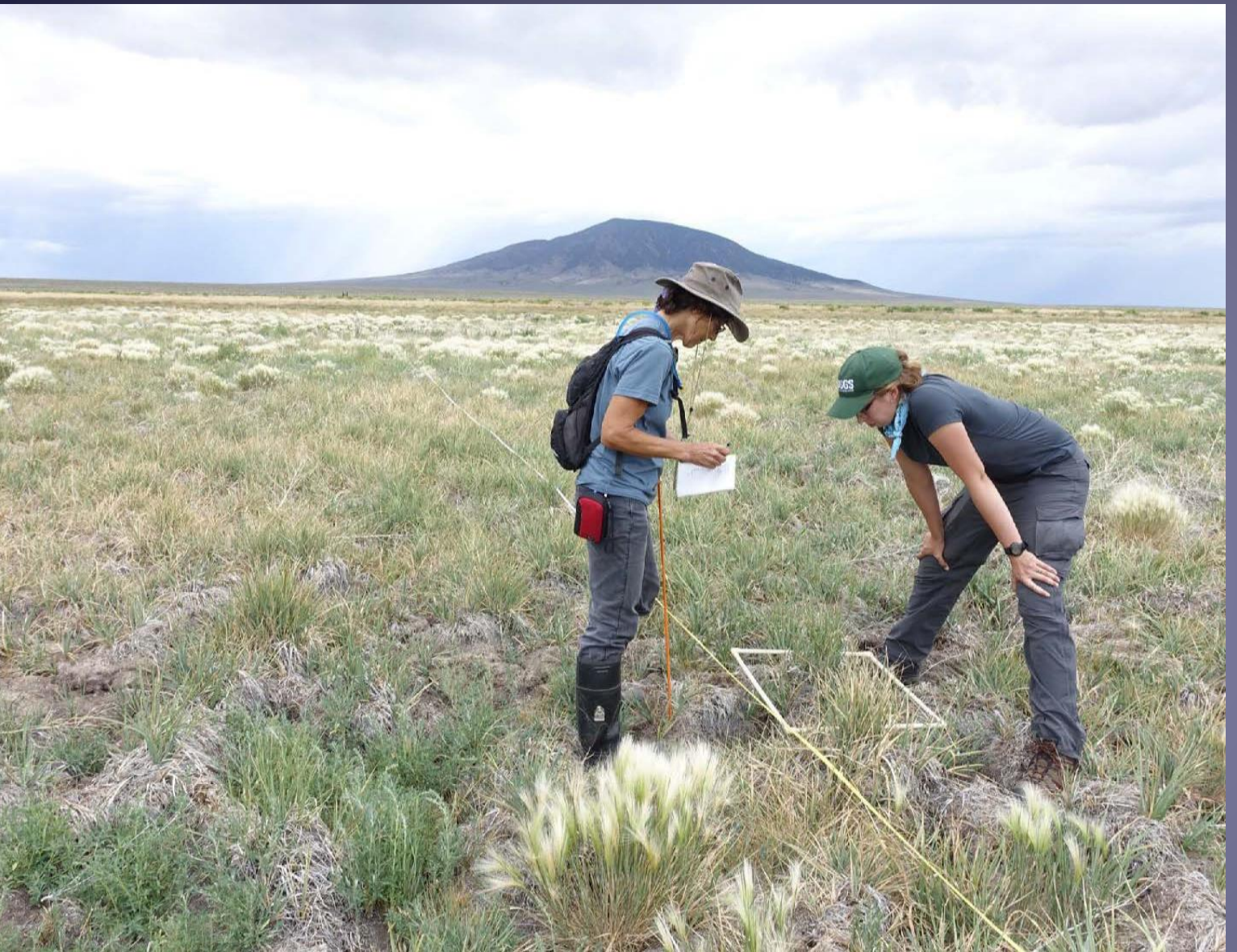

To collect the baseline vegetation data of current characteristics and conditions of the wetland, a vegetation survey was conducted at the Anderson Ranch wetlands during August of 2016.

USGS Botanist Joan Daniels and USGS Hydrologic Technician Alanna Jornigan identifying vegetation at the Anderson Ranch wetlands, August 2016. Photograph by Quan Dong, USGS.

\section{$\approx U S G S$}




\section{Vegetation Survey Classifications}

Wetland indicator status, designation, and qualitative description are from Lichvar and others (2012). The wetland indicator status and designations were used to classify vegetation in the August 2016 survey.

\begin{tabular}{|l|l|l|}
\hline Indicator status & Designation & Qualitative Description \\
\hline $\begin{array}{l}\text { Obligate } \\
\text { (OBL) }\end{array}$ & Hydrophyte & Almost always occur in wetland. \\
\hline $\begin{array}{l}\text { Facultative Wetland } \\
\text { (FACW) }\end{array}$ & Hydrophyte & $\begin{array}{l}\text { Usually occur in wetland, but may occur in } \\
\text { nonwetland. }\end{array}$ \\
\hline $\begin{array}{l}\text { Facultative } \\
\text { (FAC) }\end{array}$ & Hydrophyte & Occur in wetland and nonwetland. \\
\hline $\begin{array}{l}\text { Facultative Upland } \\
\text { (FACU) }\end{array}$ & Nonhydrophyte & $\begin{array}{l}\text { Usually occur in non-wetland, but may occur } \\
\text { in wetland. }\end{array}$ \\
\hline $\begin{array}{l}\text { Upland } \\
\text { (UPL) }\end{array}$ & Nonhydrophyte & Almost never occur in wetland. \\
\hline
\end{tabular}

Vegetation survey methods were used to identify plant species and to determine wetland indicator status.

\section{ÆUSGS}




\title{
Water Budget
}

\section{$\Delta S=P-E T+S W_{\text {in }}-R+G W_{\text {in }}-G W_{\text {out }}$}

\author{
$\Delta S=$ Change in storage$$
P=\text { Precipitation }
$$$$
E T=\text { Evapotranspiration }
$$$$
S W_{i n}=\text { Surface-water inflows }
$$$$
R=\text { Runoff (surface-water outflows) }
$$$$
G W_{\text {in }}=\text { Groundwater inflows }
$$$$
G W_{\text {out }}=\text { Groundwater outflows }
$$ \\ Where all units are volumes [ Length $\left.^{3}\right]$
}


In order to estimate the Anderson Ranch wetland water budget in the absence of data for all components, several assumptions were made:

1. The $S W_{\text {in }}$ and $R$ terms were assumed to be zero because there had been no observed surface flows into or out of the wetlands.

2. The $G W_{\text {in }}$ and $G W_{\text {out }}$ terms were assumed to be equal because of a lack of subsurface-flow information, and therefore the difference was assumed to equal zero.

\section{Assumptions}

\section{Made in This}

Water Budget

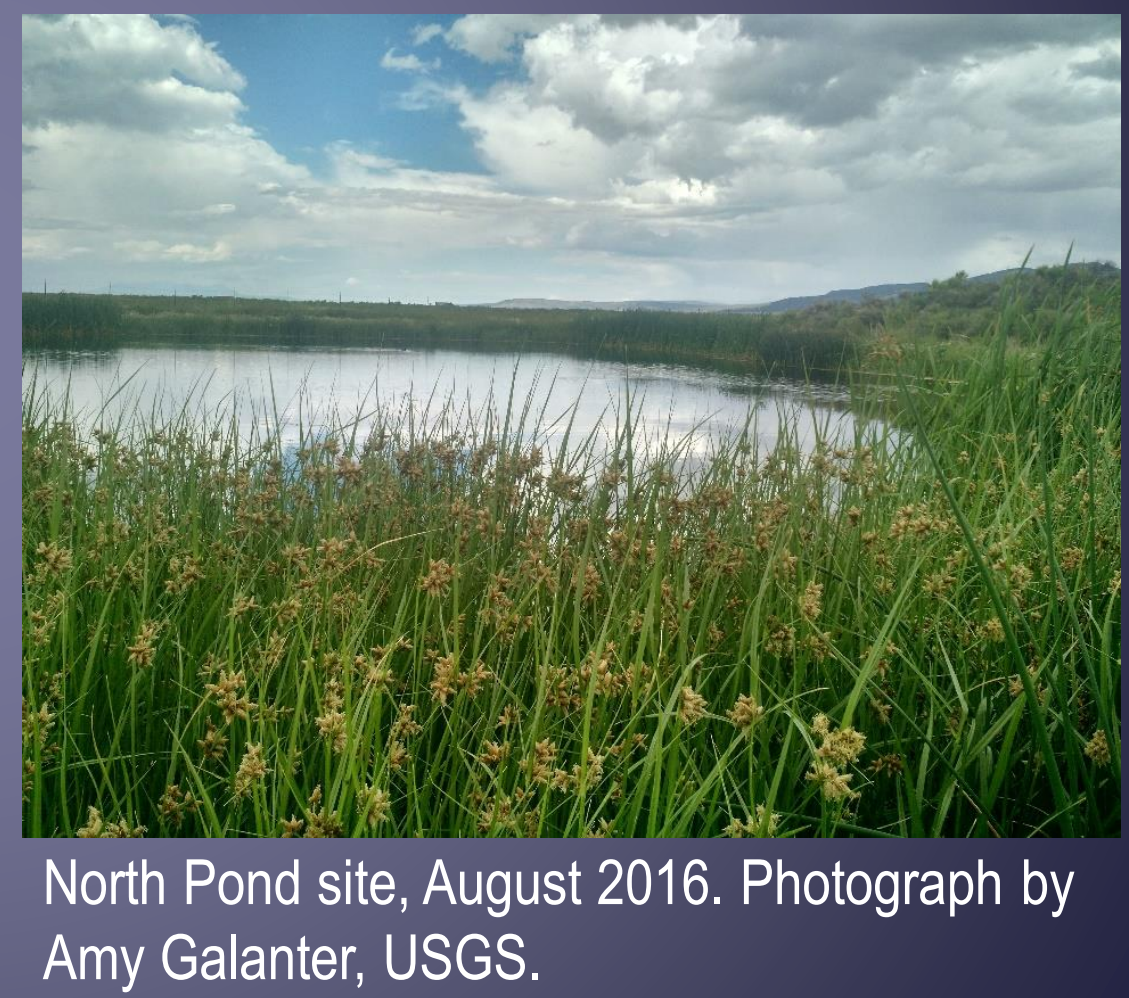




\section{Evapotranspiration (ET)}

Data from WRCC (2016)

\begin{tabular}{|c|c|c|c|c|c|c|c|c|c|c|c|c|c|c|c|}
\hline & & & \multicolumn{13}{|c|}{ Pan Evaporation (inches) } \\
\hline Station & Elevation $(\mathrm{ft}$ ) & Period of record & JAN & FEB & MAR & APR & MAY & JUN & JUL & AUG & SEP & OCT & NOV & DEC & ANNUAL \\
\hline ALAMOSA WSO AP & 7533 & $1948-2005$ & -- & -- & -- & 7.06 & 9.01 & 10.08 & 9.16 & 7.81 & 6.4 & 4.39 & -- & -- & 53.91 \\
\hline CONEJOS 3 NNW & 7907 & 1948-1960 & -- & -- & -- & 6.3 & 7.14 & 7.67 & 7.41 & 6.87 & 7.19 & 5.74 & -- & -- & 48.32 \\
\hline SAN LUIS LAKES 3W & 7536 & 1948-1955 & -- & -- & 4.5 & 6.07 & 8.51 & 9.88 & 8.49 & 7.77 & 6.57 & 4.53 & -- & -- & 56.32 \\
\hline
\end{tabular}

- Pan evaporation is measured using an aboveground Class A evaporation pan and adjusted for precipitation inputs. Due to effects of radiation and heat exchanges between water in the pan and the side walls of the pan, pan evaporation is an overestimate of evaporation from ponded surface water or wet soil, and an adjustment using a multiplication factor of 0.70 or 0.80 is suggested (WRRC, 2016).

- Differences between pan evaporation and ET depend on many factors, including vegetation type. ET can be estimated by using the canopy crop coefficient (CCC) method, which uses the evaporative demand of a region and the plant-species-specific crop coefficient (Drexler and others, 2004).

- Further work to determine appropriate crop coefficients could yield estimates of ET at the Anderson Ranch wetlands.

\section{$\approx$ USGS}




\section{Water Budget: Preliminary Conclusions}

1. Based on evaporation estimates from pan evaporation rates at nearby climate stations, evaporative (and likely ET) demand exceeds precipitation inputs.

2. Climate variability could result in higher temperatures (Chavarria and Gutzler, 2018) and increased evaporative demand, creating a larger outward flux.

3. Drought conditions could result in decreased precipitation.

4. Increased groundwater pumping could result in decreases in subsurface inflows to the Anderson Ranch wetlands.

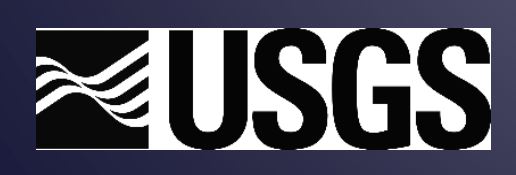




\section{Information Required to Complete a Water Budget Analysis of the Anderson Ranch Wetlands}

1. Subsurface inflows and outflows

- Collect additional groundwater-level and surface-water-level data.

- Build a groundwater/surface-water model to enable quantification of subsurface flows.

2. Historical and current extent of wetlands (for estimating the areal extent required for ET calculations)

- Complete an analysis of historical wetland extent by using Landsat imagery.

- Determine the current extent of wetlands by analyzing vegetation survey data and aerial imagery.

3. Crop coefficients for wetland vegetation

- Use results of vegetation survey and complete a literature review to determine appropriate crop coefficients for ET calculation. 


\section{Conclusions}

1. The Anderson Ranch wetlands are groundwater fed and may be the result of a regional topographic low and other geologic features.

2. The Anderson Ranch wetlands appear to be connected to other nearby wetlands.

3. Surface-water pond levels and groundwater levels at the Anderson Ranch wetlands fluctuate seasonally.

4. The hydraulic gradient in the Anderson Ranch wetlands area is from northeast to southwest.

5. The current groundwater-level elevation within the Anderson Ranch wetlands (about 7,500 ft) has not changed much since the 1950s (Winograd, 1959) as evidenced by groundwater-level contours.

6. Water maintaining the Anderson Ranch wetlands is modern and potentially vulnerable to climate variability. Deeper groundwater north of the wetlands (Stock Well) also has modern water.

7. Evapotranspiration is a main driver of the water budget at the Anderson Ranch wetlands. 


\section{Proposed Future Work}

To better understand the source of water to the wetlands, the USGS proposes to:

- Continue data collection and upgrade equipment to allow for real-time data collection to provide data to cooperators and the public quickly and to prevent data loss due to equipment failures. Long-term data collection will allow for further trend analysis.

- Analyze temperature data at AR1.

- Analyze correlations between climate data and groundwater-level data.

- Conduct drone flights (NDVI, ${ }^{8}$ infrared) to better characterize the extent of wetland vegetation and to examine groundwater-source locations.

- Analyze data from other sources, including precipitation and groundwater-level data from the NMBGMR, ${ }^{9}$ as well as data from published reports and other agencies.

- Complete the water budget. 


\section{Proposed Future Work (cont.)}

To better understand historical and future scenarios, the USGS proposes to:

- Analyze Landsat and historical imagery.

- Model climate change scenarios and analyze potential effects on the wetlands.

- Publish vegetation survey data and an interpretive report.

To support the creation of a watchable wildlife station, the USGS proposes to:

- Build interactive data collection infrastructure.

- Conduct outreach efforts.

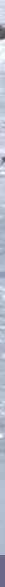




\section{References Cited}

Chavarria, S.B., and Gutzler, D.S., 2018, Observed changes in climate and streamflow in the upper Rio Grande Basin: Journal of the American Water Resources Association, v. 54, no. 3, p. 655-659.

Craig, H., 1961, Isotopic variations in meteoric waters: Science, v. 133, no. 3465, p. 1702-1703.

Drexler, J.Z., Snyder, R.L., Spano, D., and Tha Paw U, K., 2004, A review of models and micrometeorological methods used to estimate wetland evapotranspiration: Hydrological Processes, v. 18, no. 11, p. 2071-2101.

Edwards, T.M., and Guillette, L.J., Jr., 2007, Reproductive characteristics of male mosquitofish (Gambusia holbrook) from nitratecontaminated springs in Florida: Aquatic Toxicology, v. 85, no. 1, p. 40-47.

Edwards, T.M., Miller, H.D., and Guillette, L.J., Jr., 2006, Water quality influences reproduction in female mosquitofish (Gambusia holbrook) from eight Florida springs: Environmental Health Perspectives, v. 114, no. 1, p. 69-75.

Fretwell, J.D., Williams, J.S., and Redman, P.J., 1996, National water summary on wetland resources: U.S. Geological Survey WaterSupply Paper 2425, $431 \mathrm{p}$.

Hem, J.D., 1985, Study and interpretation of the chemical characteristics of natural water: U.S. Geological Survey Water-Supply Paper $2254,263 p$.

Kendall, C., and Coplen, T.B., 2001, Distribution of oxygen-18 and deuterium in river waters across the United States: Hydrological Processes, v. 15, p. 1363-1393.

Lichvar, R.W., Melvin, N.C., Butterwick, M.L., and Kirchner, W.N., 2012, National Wetland Plant List indicator rating definitions: Hanover, N.H., U.S. Army Engineer Research and Development Center, Cold Regions Research and Engineering Laboratory, ERDC/CRREL TN-12-1, 14 p.

National Oceanic and Atmospheric Administration [NOAA], 2017, VERTCON NAVD 88 minus NGVD 29 datum shift contours, accessed July 8, 2019, at https://www.ngs.noaa.gov/TOOLS/Vertcon/vertcon.html .

National Oceanic and Atmospheric Administration [NOAA], 2019, Applied Climate Information System SC ACIS Version 2 , accessed June 1, 2019, at http://scacis.rcc-acis.org/.

New Mexico Office of the State Engineer [NMOSE], 2019, New Mexico Water Rights Reporting System, Water Right Summary for RG 01119, accessed June 1, 2019, at http://nmwrrs.ose.state.nm.us/nmwrrs/index.html.

Natural Resources Conservation Service [NRCS], Aerial Photography Field Office, 2016, ortho1-1_1n_s_nm055_2016_1.zip, vector digital data, Salt Lake City, Utah, accessed August 6, 2017, at https://nrcs.app.box.com/v/naip/folder/18143730559.

\section{※USGS}




\section{References Cited (cont.)}

Plummer, L.N., Bexfield, L.M., Anderholm, S.K., Sanford, W.E., and Busenberg, Eurybiades, 2004, Geochemical characterization of ground-water flow in the Santa Fe Group aquifer system, Middle Rio Grande Basin, New Mexico (ver. 1.2, November 20, 2012): U.S. Geological Survey Water-Resources Investigations Report 03-4131, 395 p., accessed June 1, 2019, at https://pubs.usgs.gov/wri/wri034131/.

Ruleman, C.A., Thompson, R.A., Shroba, R.R., Anderson, M., Drenth, B.J., Rotzien, J., and Lyon, J., 2013, Late Miocene-Pleistocene evolution of a Rio Grande rift subbasin, Sunshine Valley-Costilla Plain, San Luis Basin, New Mexico and Colorado: Geological Society of America Special Papers, v. 494, p. 47-73.

Soil Conservation Service, 2008, 1935 15’ Quad \#014 Aerial Photo Mosaic Index: Albuquerque, N. Mex., Earth Data Analysis Center.

Uden, D.R., Hellman, M.L., Angeler, D.G., and Allen, C.R., 2014, The role of reserves and anthropogenic habitats for functional connectivity and resilience of ephemeral wetlands: Ecological Applications, v. 24, no. 7, p. 1569-1582.

U.S. Department of the Interior [DOI], U.S. Department of Agriculture, State of New Mexico, and Industrial Economics, Incorporated, 2018, Restoration plan and environmental assessment, Questa Mine Site, Questa, New Mexico: 164 p.

U.S. Environmental Protection Agency [EPA], 2017, Wetlands protection and restoration, accessed August 1, 2018, at https://www.epa.gov/wetlands.

U.S. Environmental Protection Agency [EPA], 2018, 2018 Edition of the drinking water standards and health advisories tables: EPA 822-F-18-001, 12 p., accessed June 3, 2019, at https://www.epa.gov/sites/production/files/201803/documents/dwtable2018.pdf.

U.S. Fish and Wildlife Service [USFWS], 2010, Classification of wetlands and deepwater habitats of the United States: Washington, D.C., U.S. Department of the Interior, Fish and Wildlife Service, scale 1:24,000.

U.S. Geological Survey [USGS], 2018, USGS NED 1/3 arc-second n37w106 1 x 1 degree ArcGrid 2018, raster digital data, accessed June 1, 2019, at https://nationalmap.gov/elevation.html.

U.S. Geological Survey [USGS], 2019, USGS water data for the Nation: U.S. Geological Survey National Water Information System database, accessed April 1, 2019, at https://doi.org/10.5066/F7P55KJN.

Western Regional Climate Center [WRCC], 2016, Average pan evaporation data by State, accessed June 1, 2019, at https://wrcc.dri.edu/Climate/comp_table_show.php?stype=pan_evap_avg.

Winograd, I.J., 1959, Ground-water conditions and geology of Sunshine Valley and western Taos County, New Mexico: Technical Report no. 12, p. 1-70.

\section{ॠUSGS}


Appendix: Aqueous-chemistry data for North Pond, AR1, and Stock Well *These data are also available at USGS (2019).

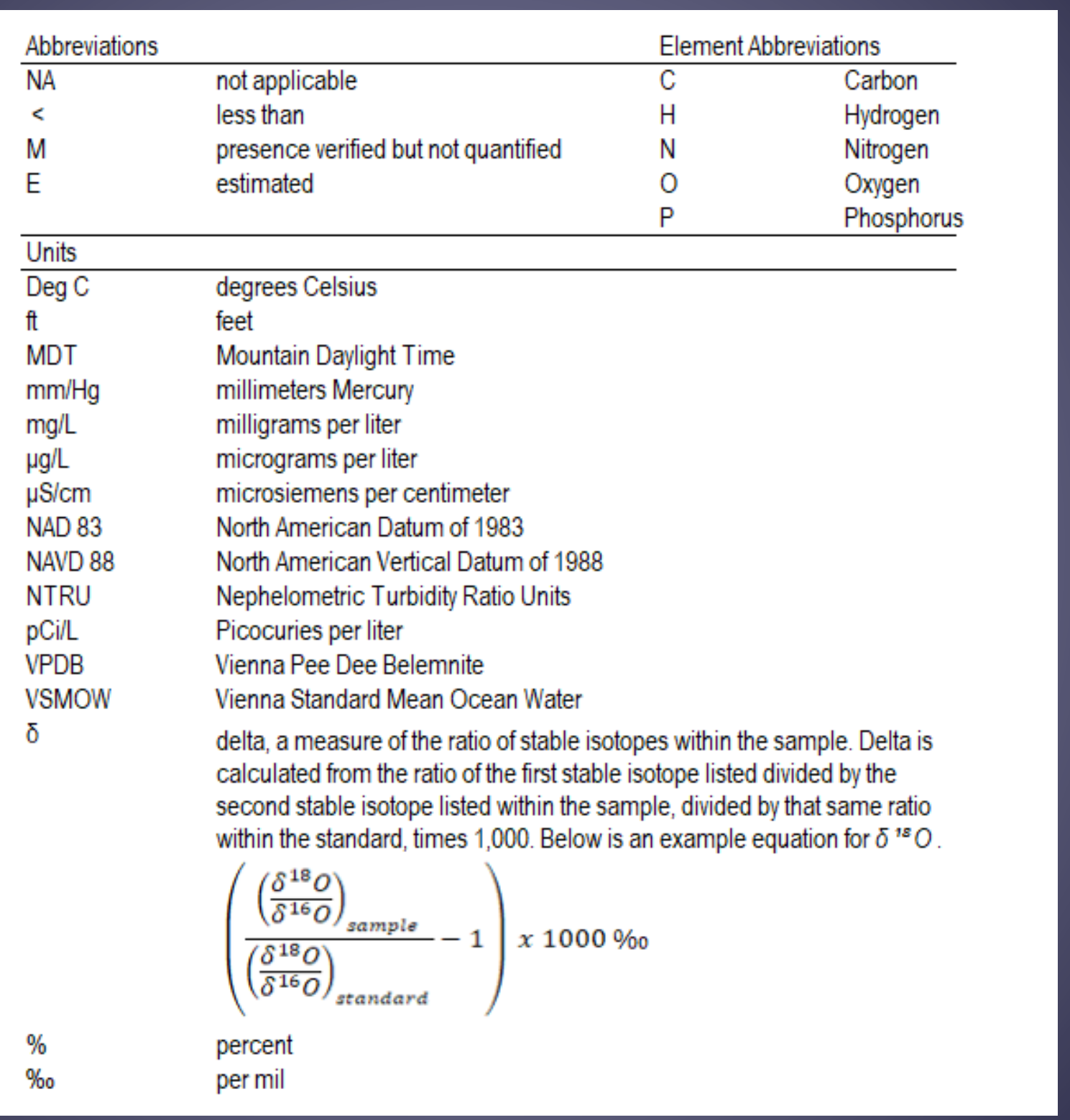




\section{Appendix (continued): Aqueous-chemistry data for North Pond, AR1, and Stock Well *These data are also available at USGS (2019)}

\begin{tabular}{|c|c|c|c|}
\hline Constituent & $\begin{array}{r}365210105364608 \\
\text { North Pond } \\
\end{array}$ & $\begin{array}{r}365204105365501 \\
\text { AR1 } \\
\end{array}$ & $\begin{array}{r}365353105360101 \\
\text { Stock Well } \\
\end{array}$ \\
\hline \multicolumn{4}{|l|}{ Site Information } \\
\hline Local identifier & 30 N.12E.01.1422 & 30N.12E.01.1414 & $\begin{array}{c}\text { 31N.13E.30.114 } \\
\text { (Projected) }\end{array}$ \\
\hline Latitude (Decimal degrees, NAD 83) & 36.86958888 & 36.86783056 & 36.89818611 \\
\hline Longitude (Decimal degrees, NAD 83) & -105.6129889 & -105.6153 & -105.6002472 \\
\hline Well depth (ft below land surface) & NA & 27 & 210 \\
\hline Screen depth (ft below land surface) & NA & $22-27$ & $110-210$ \\
\hline Elevation (ft above NAVD 88) & 7515 & 7506.98 & 7565 \\
\hline \multicolumn{4}{|l|}{ Field Properties } \\
\hline Sample date & $10 / 24 / 2016$ & $10 / 25 / 2016$ & $10 / 25 / 2016$ \\
\hline Sample time (MDT) & $14: 00$ & $10: 00$ & 14:00 \\
\hline Average depth to water [2016-2019] (ft below land surface) & NA & 0.51 & 53.5 \\
\hline Temperature (deg C) & 10.5 & 9.7 & 11.9 \\
\hline Barometric pressure $(\mathrm{mm} / \mathrm{Hg})$ & 589 & 583 & 581 \\
\hline Specific conductance, at $25 \operatorname{deg} \mathrm{C}(\mu \mathrm{S} / \mathrm{cm})$ & 864 & 582 & 257 \\
\hline Dissolved Oxygen (mg/L) & 10.3 & 5.2 & 7.6 \\
\hline Dissolved Oxygen ( $\%$ of saturation) & 120 & 60 & 92 \\
\hline $\mathrm{pH}$, field (standard units) & 8.3 & 7.5 & 7.6 \\
\hline Air temperature (deg C) & 23.9 & NA & NA \\
\hline Turbidity (NTRU) & NA & 1.6 & 6.3 \\
\hline Carbonate, inflection point titration $(\mathrm{mg} / \mathrm{L})$ & 3.1 & 0.4 & 0.1 \\
\hline Bicarbonate, inflection point titration $(\mathrm{mg} / \mathrm{L})$ & 369 & 335 & 126 \\
\hline Alkalinity (mg/L as Calcium Carbonate) & 308 & 276 & 104 \\
\hline
\end{tabular}


Appendix (continued): Aqueous-chemistry data for North Pond, AR1, and Stock Well *These data are also available at USGS (2019).

\begin{tabular}{|c|c|c|c|}
\hline Constituent & $\begin{array}{r}365210105364608 \\
\text { North Pond }\end{array}$ & $\begin{array}{r}365204105365501 \\
\text { AR1 }\end{array}$ & $\begin{array}{r}365353105360101 \\
\text { Stock Well }\end{array}$ \\
\hline \multicolumn{4}{|l|}{ Nutrients/Organics } \\
\hline Total Nitrogen $(\mathrm{mg} / \mathrm{L})$ & $<1.0$ & 3.5 & $<1.4$ \\
\hline Organic Nitrogen $(\mathrm{mg} / \mathrm{L})$ & $<0.97$ & $<0.07$ & $<0.07$ \\
\hline Ammonia $\left(\mathrm{NH}_{3}+\mathrm{NH}_{4}{ }^{+}\right)$as $\mathrm{N}(\mathrm{mg} / \mathrm{L})$ & $<0.01$ & $<0.01$ & $<0.01$ \\
\hline Ammonia as $\mathrm{NH}_{4}{ }^{+}(\mathrm{mg} / \mathrm{L})$ & $<0.013$ & $<0.013$ & $<0.013$ \\
\hline Ammonia + Organic Nitrogen as N $(\mathrm{mg} / \mathrm{L})$ & 0.97 & 0.07 & $<0.07$ \\
\hline Nitrite as $N(\mathrm{mg} / \mathrm{L})$ & $<0.001$ & $<0.001$ & $<0.001$ \\
\hline Nitrate as $N(\mathrm{mg} / \mathrm{L})$ & $<0.040$ & 3.39 & 1.34 \\
\hline Nitrate + Nitrite as N (mg/L) & $<0.040$ & 3.39 & 1.34 \\
\hline Orthophosphate $(\mathrm{mg} / \mathrm{L})$ & $<0.012$ & 0.05 & 0.084 \\
\hline Orthophosphate as $\mathrm{P}(\mathrm{mg} / \mathrm{L})$ & $<0.004$ & 0.016 & 0.028 \\
\hline Phosphorus $(\mathrm{mg} / \mathrm{L})$ & $<0.02$ & 0.05 & 0.02 \\
\hline Organic Carbon, unfiltered $(\mathrm{mg} / \mathrm{L})$ & 13.9 & 9.8 & $<0.7$ \\
\hline Organic Carbon, filtered $(\mathrm{mg} / \mathrm{L})$ & 12.4 & 0.95 & 0.44 \\
\hline \multicolumn{4}{|l|}{ Major lons } \\
\hline Calcium $(\mathrm{mg} / \mathrm{L})$ & 44.6 & 87.0 & 31.7 \\
\hline Magnesium $(\mathrm{mg} / \mathrm{L})$ & 39.9 & 14.9 & 5.39 \\
\hline Sodium $(\mathrm{mg} / \mathrm{L})$ & 98.8 & 20.0 & 13.6 \\
\hline Sodium, fraction of cations ( $\%$ in equivalents of major cations) & 43 & 13 & 22 \\
\hline Potassium $(\mathrm{mg} / \mathrm{L})$ & 8.67 & 2.27 & 1.58 \\
\hline Chloride $(\mathrm{mg} / \mathrm{L})$ & 25.3 & 2.50 & 3.94 \\
\hline Sulfate $(\mathrm{mg} / \mathrm{L})$ & 131 & 31.8 & 16.0 \\
\hline Iodide $(\mathrm{mg} / \mathrm{L})$ & 0.009 & 0.001 & 0.001 \\
\hline Bromide $(\mathrm{mg} / \mathrm{L})$ & E 0.431 & 0.066 & 0.069 \\
\hline Fluoride $(\mathrm{mg} / \mathrm{L})$ & 0.66 & 0.17 & 0.32 \\
\hline
\end{tabular}

\section{$\approx$ USGS}


Appendix (cont.): Aqueous-chemistry data for sites North Pond, AR1, and Stock Well *These data are also available at USGS (2019).

\begin{tabular}{|c|c|c|c|}
\hline Constituent & $\begin{array}{r}365210105364608 \\
\text { North Pond } \\
\end{array}$ & $\begin{array}{r}365204105365501 \\
\text { AR1 } \\
\end{array}$ & $\begin{array}{r}365353105360101 \\
\text { Stock Well }\end{array}$ \\
\hline \multicolumn{4}{|c|}{ Trace Elements } \\
\hline Silica as Silicon dioxide $(\mathrm{mg} / \mathrm{L})$ & 5.84 & 23.4 & 22.9 \\
\hline Arsenic $(\mu \mathrm{g} / \mathrm{L})$ & 1.1 & 0.57 & 0.21 \\
\hline Barium $(\mu \mathrm{g} / \mathrm{L})$ & 77.8 & 146 & 56.5 \\
\hline Boron $(\mu \mathrm{g} / \mathrm{L})$ & 83 & 8.0 & 11 \\
\hline Iron $(\mu \mathrm{g} / \mathrm{L})$ & 9.5 & 7.7 & 13.0 \\
\hline Manganese $(\mu \mathrm{g} / \mathrm{L})$ & 2.87 & 2.51 & 1.19 \\
\hline Strontium $(\mu g / L)$ & 404 & 474 & 224 \\
\hline Aluminum $(\mu \mathrm{g} / \mathrm{L})$ & 6.9 & $<3.0$ & $<3.0$ \\
\hline Lithium $(\mu \mathrm{g} / \mathrm{L})$ & 31.6 & 9.20 & 3.04 \\
\hline \multicolumn{4}{|c|}{ Isotopes } \\
\hline$\delta^{13} \mathrm{C}(\%) \mathrm{VPDB}$ & NA & -15.08 & -11.82 \\
\hline${ }^{14} \mathrm{C}$ (\% modern carbon, normalized) & NA & 112.6 & 98.92 \\
\hline${ }^{14} \mathrm{C}$ Counting error ( $\%$ modern carbon) & NA & 0.260 & 0.280 \\
\hline$\delta^{2} \mathrm{H} /{ }^{1} \mathrm{H}(\%)$ VSMOW & -54.70 & -98.40 & -98.60 \\
\hline$\delta^{18} \mathrm{O} /{ }^{16} \mathrm{O}(\%)$ VSMOW & -4.47 & -13.23 & -13.37 \\
\hline$\delta{ }^{15} \mathrm{~N} /{ }^{14} \mathrm{~N}(\%)$ & NA & 5.61 & 5.13 \\
\hline$\delta^{18} \mathrm{O} /{ }^{16} \mathrm{O}$, nitrate water filtered $(\%)$ & NA & -2.25 & -2.31 \\
\hline Tritium $(\mathrm{pCi} / \mathrm{L})$ & NA & 19.3 & 12.7 \\
\hline \multicolumn{4}{|c|}{ Other } \\
\hline $\mathrm{pH}$, lab (standard units) & 8.3 & 7.9 & 7.8 \\
\hline Carbon dioxide, unfiltered $(\mathrm{mg} / \mathrm{L})$ & 2.7 & 18 & 5.4 \\
\hline Hardness, water, as calcium carbonate $(\mathrm{mg} / \mathrm{L})$ & 276 & 279 & NA \\
\hline Hardness as bicarbonate $(\mathrm{mg} / \mathrm{L})$ & 276 & 279 & 102 \\
\hline Dissolved solids dried (mg/L) & 549 & 277 & 164 \\
\hline Dissolved solids sum $(\mathrm{mg} / \mathrm{L})$ & E 540 & 363 & 164 \\
\hline
\end{tabular}

